David LOMBARD

University of Liège

Liège, Belgium

david.lombard@uliege.be

\title{
THOREAU AND THE CAPITALOCENE
}

Recommended Citation: Lombard, David. "Thoreau and the Capitalocene." Metacritic Journal for Comparative Studies and Theory 4.2 (2018): https://doi.org/10.24193/mjcst.2018.6.02

\begin{abstract}
This essay will serve the double purpose of investigating the aesthetic dimensions of Thoreau's environmental philosophy as depicted in his classic memoir Walden (1854) while examining the philosophical and political implications of its tendency to break down the boundaries between natural and technological landscapes. Although critics have tended to identify Thoreau as deeply rooted in an Emersonian transcendentalist tradition viewing nature as an organized and holistic "whole”, I will argue that Thoreau's ecophilosophy seeks to reconcile the idealistic with the empirical pole and highlight the tensions between natural and technological objects and situations. I will start by studying how Thoreau approaches man-made technologies and develops a proto-ecocritical form of the sublime. I will also argue that a reconsideration of Thoreau's poetics sheds a new light on the goals of environmental (non)fiction and urges the reader to reconsider the concept of the Anthropocene as the Capitalocene.
\end{abstract}

Keywords: Thoreau, technology, sublime, Capitalocene, ecocriticism, ecophilosophy, nonfiction

"The laboring man has not leisure for a true integrity day by day; he cannot afford to sustain the manliest relations to men; his labor would be depreciated in the market. He has no time to be anything but a machine." (Henry David Thoreau, Walden; or, Life in the Woods) 
As Eileen Crist writes, "what Henry Thoreau might have thought of "the Anthropocene »" illustrates "the poverty of our nomenclature" insofar as critics seek to introduce new concepts without trying to solve the crisis caused by "the Age of Man” (Crist 26-27). In the current age of the Anthropocene, in which "there is no more nature that stands apart from human beings", the Western (or European) conception of nature as separate from human activities is being constantly challenged and debunked (Purdy 13). Still, (eco)critics do not seem to have reached a consensus on the concept that would best illustrate humans' responsibility toward their environment and the toxic impact of contemporary socio-economic systems. In his famous memoir Walden; or, Life in the Woods (1854), Henry David Thoreau laid the foundation for an aesthetics that could break down the boundaries between natural and technological landscapes, namely the "toxic sublime". The notion of the "toxic sublime", to which I will return further in this essay, can also be used to analyse Thoreau's socio-political agenda inasmuch as it urges the reader to rethink early descriptions of anthropocenical situations as being more representative of the Capitalocene or "the Age of Capital" than "the Age of Man".

\section{From Divine Nature to the Technological Sublime}

Motivated by Ralph Waldo Emerson's philosophy, Thoreau first put into practice transcendentalist theories by experiencing the outside of the city of Concord, and more specifically Walden Pond in 1845. In Walden, Thoreau's main purpose was to live with the "necessary of life" and to reject useless and meaningless luxuries (Thoreau, Walden 10). In fact, he believed that the nineteenth-century economy and lifestyle were overwhelmed by "materialism and commercialism", which were the causes of superficial needs that impoverished human beings spiritually (Manzari 1). However, before being concerned by the emerging capitalism and industrialism, Thoreau's main focus was on praising divine nonhuman nature.

Indeed, Thoreau's first aesthetic approach consisted in describing nature as "pure", "mysterious" and "divine" as well as separate from mankind. For example, in Natural History of Massachusetts, he writes that "Nature is mythical and mystical always" (Thoreau, Natural History 21) and, in A Winter Walk October, he claims that "the wonderful purity of nature [in winter] is a most pleasing fact" (Thoreau, Winter Walk 32). In the same text, Thoreau refers to sounds of civilization such as "the chopping of wood" as "Infernal sounds" in comparison to the sounds of "the primeval 
nature" (Thoreau, Winter Walk 30). Indeed, Thoreau subscribes to Leo Marx's theory of the "machine in the garden", which is defined by the "tension" or "noise" that "arouses a sense of dislocation, conflict, and anxiety" and "clash[es] through harmony" (Marx 15-17). He also favours the "simplicity and purity of a primitive age" over the landscapes of "towns and cities", thus promoting a pastoral or romantic view of nature that emphasizes the dualism between towns and nature (Thoreau, Winter Walk 35). Yet, Thoreau ambiguously distances himself from this romantic point of view to initiate discussions on artificial forms of nature, on science, and on humans' dominating influence in the landscape. For example, in Natural History of Massachusetts, he acknowledges that "the true man of science will know nature better by his finer organization; he will smell, taste, see, hear, feel, better than other men" (Thoreau, Natural History 25). This empirical approach is reminiscent of Edmund Burke's theory of the sublime inasmuch as Burke "maintains that our knowledge of the world is derived entirely from the evidence of the senses: what we can see, taste, touch, and smell" (Shaw 49). Despite his transcendentalist and romantic influences, Thoreau attempts to reconcile the empirical or scientific with the idealistic pole.

For instance, if Thoreau is convinced that there is "primeval" nature outside of towns, he still appreciates human efforts to insure a sense of "freshness" by designing "gardens" with "fences" of "bough[s]" which permit the traveller not to be "offended by violent contrasts" while crossing the country to reach the "pure" remote parts of nature (Thoreau, Winter Walk 40). The landscape of the "garden", this artificial transposition of nature, almost serves as an extension of nature after the farmers' backyards. Though referred to as "fences", the natural elements of the "boughs" deceive the eye of the aesthetic traveller who is heading for a "pure" form of nature. In line with this comment, Thoreau argues in KTAADN that "it is difficult to conceive of a region uninhabited by man" since "we habitually presume his presence and influence everywhere" (Thoreau, KTAADN 60). Although he continues his description by sustaining that the "no man's garden" and "vast and drear and inhuman" nature exist, Thoreau partially recognizes man's predominant "presence and influence", which is the fundamental argument of the Anthropocene.

At the time he was writing KTAADN, Civil Disobedience and the first pages of Walden, Thoreau was also writing his autobiographical piece entitled $A$ Week on the Concord and Merrimack Rivers (Cramer 99). In a long and enigmatic passage, which 
has not been included in all the editions of the text, Thoreau uses a dubious metaphor involving nature and human technology to convey a sense of interconnectedness in the realm of nature:

Travelling on foot very early one morning due east from here about twenty miles, from Caleb Harriman's tavern in Hampstead toward Haverhill, when I reached the railroad in Plaistow, I heard at some distance a faint music in the air like an Æolian harp, which I immediately suspected to proceed from the cord of the telegraph vibrating in the just awakening morning wind, and applying my ear to one of the posts I was convinced that it was so. It was the telegraph harp singing its message through the country, its message sent not by men, but by gods. Perchance, like the statue of Memnon, it resounds only in the morning, when the first rays of the sun fall on it. It was like the first lyre or shell heard on the seashore, that vibrating cord high in the air over the shores of earth. So have all things their higher and their lower uses. I heard a fairer news than the journals ever print. It told of things worthy to hear, and worthy of the electric fluid to carry the news of, not of the price of cotton and flour, but it hinted at the price of the world itself and of things which are priceless, of absolute truth and beauty (Thoreau, Walden 143).

Although it is unclear whether Thoreau refers to an actual telegraph cable or not, the comparison is an attempt to include human technology in an aesthetic description of nature. Through his sense of hearing, Thoreau identifies the pleasing sound of the "telegraph harp" which does not send man's message but gods' message. The "electric fluid" that "carr[ies] the news" could also be interpreted as the natural energy or "wildness" that guarantees ecosystemic balance between species. Interestingly, Thoreau also highlights that this "electric fluid" carries the news of "priceless things" such as "absolute truth and beauty" and thus avoids any relation to commerce. Thoreau adopts here an aesthetics that does not dodge early forms of human technology such as the "railroad" or the "telegraph". Technology is not rejected for itself, for its man-made and therefore "impure" essence, but rather for what it symbolizes, namely commercial communication and a new market ideology. This extract is an example of the technological sublime inasmuch as Thoreau does not consider "technology [as] alien to landscape, but integral to it" (Nye 10). In Walden, Thoreau realizes this experience in more concrete and critical terms by finding the sublime in "contemplating human creations" such as "railroads" (Nye 10). In 
addition, he also uses his "lower senses" which, as Michel Delville writes, can "enrich and complexify human perception" (Delville 88).

\section{Walden, the Toxic Sublime, and the Capitalocene}

Although there is no dearth of writings on Thoreau's philosophy of nature, very little attention has so far been paid to his relationship to the senses as vehicles of understanding and to his symbolism of the natural and technological landscapes. In fact, his multi-sensorial approach to nature is fundamental in any attempt to interpret the meaning of his descriptions of human technologies. First, all of Thoreau's senses are active as he experiences a form of nature that he describes as "divine". For example, Thoreau appreciates the taste of "sand cherr[ies]", which are "scarcely palatable" (Thoreau, Walden 290). More interestingly, he refers to the "wild holly berries" as "mak[ing] the beholder forget his home with their beauty, and he is dazzled and tempted by nameless other wild forbidden fruits, too fair for mortal taste" (Thoreau, Walden 362). This depiction of the "forbidden fruits", which are too "holy" to be tried by "mortal taste", still echo a divine view of nature as the "Garden of Eden restored" (Worster 9). Nevertheless, his description of the "lake" as "the earth's eye; looking into which the beholder measures the depth of his own nature" evokes an evolution toward a more subjective aesthetics (Thoreau, Walden 350). Indeed, this comparison highlights Thoreau's affinities with Immanuel Kant's theory of the sublime insofar as both thinkers experience "natural objects" by means of sensorial perception and imagination (Brady 101). Through this subject-oriented approach, Thoreau is capable of "measur[ing] [himself] relative to nature" and no longer feels "insignificant" but free in the natural landscape (Brady 93-95). However, Thoreau does not subscribe to Emerson's idealistic "aggressive optimism" insofar as Thoreau supposes "that natural facts properly perceived and accurately transcribed must yield truth" (Crumbley 41) and therefore "adopts the tone of a hard-headed empiricist" (Marx 243).

Besides his multi-sensorial approach to nature, Thoreau writes with an idiosyncratic language in the previously mentioned passages. His economy of language would later echo in Russian formalist theories such as Viktor Shklovsky's process of poetic "defamiliarization" of the real. Indeed, Shklovsky argues that "only the creation of new forms of art can restore to man sensation of the world, can resurrect things and kill pessimism" and thus promotes "poetic language" as opposed 
to "practical language" (Crawford 209-210). Consequently, Thoreau uses his symbolical and poetic language to "defamiliarize" the common view of natural facts and "restore [the] perception of the world" as the "centre of aesthetic experience" (Crawford 210-212). In other words, Thoreau's characteristic descriptions of natural elements shed a new light on environmental experience and awareness (Phillips 296). Empiricism and imagination both serve Thoreau's purpose of understanding the physical and conceptual complexity of nature while fully realising his sense of place. As Daniel Peck writes, this ecological form of aesthetics could also be perceived as "the need for a new foundation mythology, one that would link human activity to an actual place" (Crumbley 36). Nevertheless, this way of conceptualizing nature as encompassing both "human activity" and the natural or nonhuman also calls for a redefinition of Thoreau's aesthetic approach to nature. While Thoreau's use of complex linguistic forms and empirical experiences help him to translate the "mysterious" beauty of sublime nature, his philosophical enquiry is also characterized by his intention to criticize the political forces of the technological sublime as dissocializing and "unworlding" humans.

In his compelling analysis of technology in US pastoral literature, Leo Marx argues that Thoreau maintains a view of technology as constantly disturbing his pursuit of the pastoral dream. Marx mentions that Thoreau's first reference to technology is when he hears the sound of "the rattle of railroad cars, now dying away and then reviving like the beat of a partridge, conveying travelers from Boston to the country" (Thoreau, Walden 291). This train will then become the author's preoccupation, one of his representations of the "machine" being particularly apocalyptic:

when I hear the iron horse make the hills echo with his snort like thunder, shaking the earth with his feet, and breathing fire and smoke from his nostrils (what kind of winged horse or fiery dragon they will put into the new Mythology I [do not] know), it seems as if the earth had got a race now worthy to inhabit it. If all were as it seems, and men made the elements their servants for noble ends! (Thoreau, Walden 292).

The "iron horse" producing "thunder", "fire and smoke", and making the earth tremble, appears as an apocalyptic and mythological illustration of the train. Thoreau also specifies that this symbol of US increasing industrialism is manufactured as "servants for [man's] noble ends". He also repeatedly criticizes the symbolism of the 
"engine with its train of cars" which transforms the wild huckleberries and other natural fruits and vegetables into commercial goods. However, the next part of his description conveys a less radical approach to the "machine" and to commerce in general:

The stabler of the iron horse was up early to put the vital heat in him and get him off. If the enterprise were as innocent as it is early! (...) All day the fire-steed flies over the country, stopping only that his master may rest, and I am awakened by his tramp and defiant snort at midnight, when in some remote glen in the woods he fronts the elements incased in ice and snow (...) I hear him in his stable blowing off the superfluous energy of the day, that he may calm his nerves and cool his liver and brain for a few hours of iron slumber. If the enterprise were as heroic and commanding as it is protracted and unwearied! (Thoreau, Walden 293).

This description of the train almost functions as a process of dehumanization or a form of zoomorphism which seeks to associate animal or nonhuman characteristics with man-made or human technology. In this way, the train becomes an "iron horse" that "may calm his nerves and cool his liver and brain for a few hours of iron slumber". He also refers to the train or the rail company as an "early", "protracted" and "unwearied enterprise". Though impressive and "defiant", the "iron horse" does not seem to obstruct Thoreau's philosophical enquiry inasmuch as he devotes a long passage to describe the machine. On the contrary, the last sentence of this extract reveals that Thoreau is more worried about the negative aspects of the developing and unrestricted "enterprise" of what this technology represents, which is closely related to nineteenth-century commerce and industrialism:

Commerce is unexpectedly confident and serene, alert, adventurous, and unwearied. It is very natural in its methods withal, far more so than many fantastic enterprises and sentimental experiments, and hence its singular success. I am refreshed and expanded when the freight train rattles past me, and I smell the stores which go dispensing their odors all the way from Long Wharf to Lake Champlain, reminding me of foreign parts, of coral reefs, and Indians oceans, and tropical climes, and the extent of the globe. I feel more like a citizen of the world at the sight of the palm-leaf which will cover so many flaxen New England heads the next summer, the Manilla hemp and cocoanut husks, the old junk, gunny bags, scrap iron, and rusty nails (Thoreau, Walden 294-295). 
In this celebrating description, human commerce is depicted as "natural in its methods". Thoreau feels "refreshed" when he can behold the train and "smell the stores" that are "dispensing their odors". In addition, through his senses of smell and sight, the author goes through a transcendental experience that makes him feel like "a citizen of the world". More specifically, Thoreau's use of the lower sense of smell is particularly relevant in our "cultural environment which privileges the 'verbivocovisual', or what Hegel called «the two theoretical senses of sight and hearing»" insofar as it allows him to extend his environmental awareness to a global scale (Delville 88-89). In other words, Thoreau displays a multi-sensorial and holistic aesthetic that does not reject the "machine" or the train but, rather, finds it aweinspiring and useful in the process of connecting natural facts on a larger scale. Although the "machine" is a man-made, dangerous and unstoppable "Atropos", Thoreau recognizes that it is a powerful human achievement, which is an example of the technological sublime. More specifically, the problematic with the technological object lies in its economic potential which is drastically and negatively changing human social and proto-ecological values. Thoreau respects the "courage" and "heroism" of workers who do not rest until "the storm sleeps or the sinews of their iron steed are frozen". What Thoreau condemns is the power of the machine that does not regard the work as courageous or rewarding but only seeks profit and wealth. The "machine" is a symbol of capitalism, which is gradually transforming both the landscape and social relationships. "To do things «railroad fashion» is now the byword", he claims, "and it is worth the while to be warned so often and so sincerely by any power to get off its track". The railroad is expanding at the expense of environmental stability and its "fashion" also changes humans' behaviors and their relationships to work and nature. Humans are themselves becoming "machines" because their "labor [is] depreciated in the market" (Thoreau, Walden 201-202). Through what can be categorized as a "toxic sublime" experience, Thoreau describes the "freight train" as symbolizing the confluence of global transportation and commerce and the "toxic" capitalistic ideology that it represents. In the middle of the nineteenth century, a time when humans significantly changed their environment and the market economy, Thoreau urges the reader to reconsider the impact that capitalism has had on the making of the Anthropocene or, rather, the "Capitalocene". The "toxic sublime" could be an appropriate critical concept to study this innovative approach to the "Capitalocene". 
Jennifer Peeples defines the "toxic sublime" as "the tensions that arise from recognizing the toxicity of a place, object, or situation, while simultaneously appreciating its mystery, magnificence and ability to inspire awe" (Peeples 375-380). These "tensions" were already apparent in US nature writing in which writers dialectically "juxtapose and blend" the registers of "rhapsody or epistemology" and "jeremiad or politics" to endeavour to understand the relationship between humans and the natural world while trying to convince readers to become ecologically responsible (Slovic 84-100). Even though toxic political forces are not always "visible" to the human eye or directly perceptible by the human senses, the notion of the toxic sublime allows the literary or cultural critic to examine abstract "toxic" objects and ideologies such as Morton's "hyperobjects" - "things that are massively distributed in time and space relative to humans" (Morton 1). For example, through the use of his lower senses, Thoreau becomes aware of the "invisible toxicity" of capitalism that "exceeds human perception" and manages to express it in his writing. Although Leo Marx's analysis of the pastoral mode offers a compelling dialectical approach, it is still embedded in the pastoral mode. The pastoral mode still tends to idealize the realm of nature as a "pristine" realm, separate from human endeavours, and to systematically condemn urban or industrial growth. In contrast, the toxic sublime avoids such binary, Cartesian dualisms between nature and culture or technology to permit critical analyses of human achievements. Consequently, a closer study of Thoreau's fundamental text through the lens of the toxic sublime opens the door to further investigation on the negative aspects of the technological sublime, namely the "Capitalocene" or the alienating effects of unfettered capitalism.

Recent critics of the Anthropocene have argued that the concept of the Anthropocene fails to "couple" society with nature but, rather, reinforce Cartesian dualisms between nature and society or culture (Crist 29). As an alternative, these critics suggest that we should "unmake" the "Capitalocene" (Haraway 54), a negatively connoted term that is used to define our current geo-ecological epoch which "understands the degradation of nature as a specific expression of capitalism's organization of work" (Moore 111). Jason W. Moore also adds that understanding work as a "multispecies and manifold geo-ecological process" allows critics to reconsider technology as firmly implanted in the "natures co-produced by capitalism" or "Cheap Natures". As a result, the conception of capitalism as a "system of unpaid work" encourages humans to view nature as a "free gift", as an inexhaustible resource 
to be infinitely exploited (Moore 112). In the previously analysed passages from Thoreau's Walden, technology has the same function of dehumanizing labour and fostering competition in society. The "machines" or railroads are part of a process of "capitalist mechanization" which contributes "to appropriat[ing] a rising physical mass of unpaid work/energy from manifold natures" (Moore 92). More largely, Thoreau leads the reader into thinking that capitalism started a process of "unworlding" by transforming humans in the Anthropocene into an uncaring and "invasive species" which seeks expansion, progress and thriving, without paying attention to the preservation of other parts of the ecosystem. In other words, humans have become this "invasive species" that expands globally, far beyond their original habitat, and now threaten the extinction of the "native" species that used to live in stable ecosystems. While the symbols of different cultures, the "odors" of many places, could be brought together thanks to commerce, a capitalist conception of technology alienates humans from an ecological perspective on the physical world they inhabit. In that sense, Thoreau's passages about the machine and commerce allude to a proto-ecocritical conception of humans in the Anthropocene inasmuch as humans' destructive effects on the environment have been displaced from a local to the global scale. Moore's approach would therefore be appropriate when considering Thoreau's memoir inasmuch as it endeavours to go beyond the "dualism capitalism/nature" and sheds light on the unstable relationship humans have maintained with both nature and technology (Campagne 57). ${ }^{1}$

The notion of the "machine" has therefore several negative connotations for Thoreau. First, the machine is the noisy technologies - the train and railroads which disturb the philosopher's experience of the pastoral dream. Although imposing and awe-inspiring, it also symbolizes the alienating effects of laissez-faire capitalism. This is the main reason why Thoreau also uses the term "machine" to define the state of the worker whose labour has been devalued, regarded as "unpaid". In addition, this conception of the machine is precisely what critics of the "Capitalocene" intend to deconstruct. If there is nothing intrinsically "ugly" in human technologies, the system

\footnotetext{
${ }^{1}$ Although the distinction between the Anthropocene and the Capitalocene is relevant in this analysis of Thoreau's text, the reader should know that the concept of the Capitalocene does not include all forms of "toxic socio-economic systems". Critics such as Marshall Goldman and Armel Campagne have underlined the detrimental effects that socialist systems like Soviet-era communism have had on both environment and social relationships (e.g. The Spoils of Progress: Environmental Pollution in the Soviet Union [Cambridge: MIT Press, 1972]). One may also think of the Chinese blend of capitalism and communism throughout the twentieth century, which gave rise to similar socio-environmental problems.
} 
they epitomize has been proven unstable, inequitable and devastating. Walden includes several attempts to deconstruct rising capitalism while critically analysing the "elements of capitalist civilization which appear to have no immediate relation to ecology, but which are in fact internal conditions of its possibility" (Hartley 165). Similarly, Thoreau identifies the US government in Civil Disobedience as the unjust "machine of the government", inviting the reader to "let [her] life be a counterfriction to stop the machine" (Thoreau, Civil Disobedience 83-84). According to Thoreau, the "machine" of the government was also supporting a dehumanizing world-ecology that seeks profit and favours unpaid work and slavery over social and environmental justice. Although capitalist mechanization gave evidence of commercial success, it compelled numerous authors who were influenced by Thoreau's ecophilosophy to critically consider the political forces of technology as potentially dehumanizing and unworlding.

\section{Post-Thoreauvianism and the Unmaking of the Capitalocene}

Substantial evidence in Jon Krakauer's Into the Wild (1996) and Carine McCandless's The Wild Truth (2014) confirms that Christopher McCandless admired Thoreau and the transcendentalists' writings. In Into the Wild, Krakauer writes that McCandless's main goal was to isolate himself from civilization and from all forms of modern technologies:

Two years he walks the earth. No phone, no pool, no pets, no cigarettes, ultimate freedom. An extremist. An aesthetic voyager whose home is the road. (...) And now after two rambling years comes the final and greatest adventure. The climactic battle to kill the false being within and victoriously conclude the spiritual revolution. Ten days and nights of freight trains and hitchhiking bring him to the great white north. No longer to be poisoned by civilization he flees, and walks alone upon the land to become lost in the wild (Krakauer, 163, emphasis added).

In this extract found in the bus in which McCandless lived the last days of his life, man-made objects are described as toxic or "poisonous" for McCandless's spiritual experience in nature, which he considers as a springboard for his self-realization. At first, McCandless falls in the trap of pastoral idealization insofar as he perceives nature as "wild" and "pure", thus being dualistically opposed to civilization and technology. Nonetheless, his attempt to come back to civilization during the very last 
days of his life obscures his yearning for solitude in the wilderness of Alaska. Carine McCandless speculates that Chris McCandless may have "felt regret for leaving home the way he did" or missed "the communal feel of the society he had shrugged aside for its conformity" (McCandless 139). Chris McCandless felt he could reconnect with a healthier way of living in nature that would not be "poisoned by civilization". Still, McCandless's relationship with techno-natural places is complex insofar as isolation in nature does not give him the social interactions that are necessary to his happiness. His toxic sublime experience occurs when he idealizes the "wilderness" as a pristine and awe-inspiring place, where one's honest character is not altered by technologies and consumerist ideologies, whereas it is his idealistic and individualistic approach to nature that plunged him into the toxic state of loneliness which eventually caused his death.

Directly influenced by Thoreau's Walden, Ken Ilgunas's Walden on Wheels (2013) is another example of a Thoreauvian critique of capitalism or, more specifically, US student debts. In his memoir, Ilgunas's van serves the same purpose as Thoreau's cabin at Walden Pond, since it becomes a means of building himself "a culture of [his] own" through solitude and introspection (Ilgunas 258). After his work experience in Alaska, Ilgunas realizes that consumerist culture creates and promotes "envy", "needs", and insatiable "discomfort," while he only needs "people", "community" and a "meaningful role to play in [his] society" (Ilgunas 254). Ilgunas clarifies a fundamental problem which is that, in order to end the Capitalocene, humans have to evolve toward drastic cultural and systemic shifts. In that sense, the toxic sublime works in reverse inasmuch as he argues that what many people seek and value as essential to their survival should be understood as being "toxic". For instance, he writes that "comfort and security, it seems, when overprescribed, can be poisons to the soul - an illness that no amount of love can cure, freedom being the only antidote (Ilgunas 134$)^{2}$. As shown by the author, comfort can appear as a cultural problem inasmuch as, in Western civilizations, humans tend to respond to their need for comfort by accumulating consumables and waste and not by developing sustainable socio-environmental relationships. The "Capitalocene" could only be overcome if it is recognized as culturally and technologically specific.

\footnotetext{
${ }^{2}$ Emphasis added.
} 
Indeed, Thoreauvian literature portrays nature as a concept and physical entity that is intertwined between scientific and romantic aesthetics and ideologies 3 . Nature is never fully "disenchanted" or "neutralized" and ultimately transformed into a "scientific «environment»" that would always be easily "controllable" and scientifically definable (Zwart 142). Nor can nature become a separate, strictly nonhuman, "mysterious" and "different world" because of the use of literary artifices (Zwart 142-143). Thoreau and Thoreauvian authors try to break down the barriers between the idealistic or natural and the empirical or technological. In other words, Thoreau shows that there is something "wild" in human nature and that nature can also be somehow technological. To end the Capitalocene, one must first recognize the aesthetic dangers of perceiving nature as "neutralized" because it leaves the door opened to the unlimited exploitation of natural resources. One must also endeavor to question romantic and idealist representations that tend to mystify and estrange nature insofar as they reinforce the Cartesian dualisms between humans and nonhumans, and nature and culture. Only by extending the toxic sublime and (postThoreauvianism to accommodate for a larger compendium of methods than those which are described in this essay can one hope to come to terms with the complexities

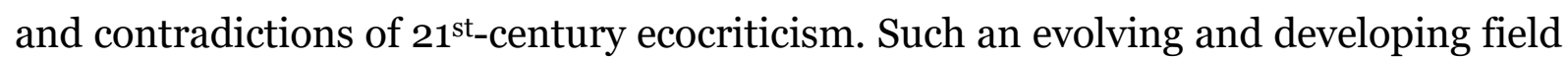
of study may prove one of the forming paradigms out of which such a project may emerge.

\section{References}

Brady, Emily. "Reassessing Aesthetic Appreciation of Nature in the Kantian Sublime." The Journal of Aesthetic Education, vol. 46, no. 1, 2012: 91-109.

Campagne, Armel. Le capitalocène: Aux racines historiques du dérèglement climatique. Paris, Divergences, 2017.

Cramer, Jeffrey S. "Introduction to A Week on the Concord and Merrimack Rivers." The Portable Thoreau. Edited by Jeffrey S. Cramer. Penguin Books, 2012: 99100.

Crawford, Lawrence. "Viktor Shklovskij: Différance in Defamiliarization." Comparative Literature, vol. 36, no. 3. 1984: 209-219.

\footnotetext{
3 By "Thoreauvian" literature, I mean literary texts (fiction and nonfiction) that are strongly influenced by Thoreau's writings and/or can be considered as part of Thoreau's literary and/or philosophical legacy.
} 
Crist, Eileen. "On the Poverty of Our Nomenclature." Anthropocene or Capitalocene? Nature History, and the Crisis of Capitalism. Edited by Jason W. Moore. Kairos, 2016: 14-33.

Crumbley, Paul. "Contesting the sublime: new versions of an alternative American tradition." SPELL: Swiss papers in English language and literature, 2002: 29-43.

Delville, Michel. "Senses." Literature Now: Key Terms and Methods for Literary History. Edited by Sascha Bru, Ben De Bruyn \& Michel Delville. Edinburgh University Press, 2016: 87-97.

Haraway, Donna J. "Staying with the Trouble: Anthropocene, Capitalocene, Chtulucene." Anthropocene or Capitalocene? Nature History, and the Crisis of Capitalism, edited by Jason W. Moore. Kairos, 2016: 34-76.

Hartley, Daniel. "Anthropocene, Capitalocene, and the Problem of Culture." Anthropocene or Capitalocene? Nature History, and the Crisis of Capitalism, edited by Jason W. Moore. Kairos, 2016: 154-165.

Ilgunas, Ken. Walden on Wheels: On the Opened Road From Debt to Freedom. Las Vegas, Amazon Publishing, 2013.

Krakauer, Jon. Into the Wild. New York, Anchor Books, 1997.

Manzari, Alireza. "Henry David Thoreau: Literary Transcendentalism." English Language and Literature Studies, vol. 2, no. 4, 2012: 1-8.

Marx, Leo. The Machine in the Garden: Technology and the Pastoral Ideal in America. New York, Oxford University Press, 2000.

McCandless, Carine. The Wild Truth. New York, HarperOne, 2014.

Moore, Jason W. "The Rise of Cheap Nature." Anthropocene or Capitalocene? Nature History, and the Crisis of Capitalism. Edited by Jason W. Moore. Kairos. 2016: 78-115.

Morton, Timothy. Hyperobjects: Ecology and Philosophy after the End of the World. Minneapolis, University of Minnesota Press, 2013.

Nye, David E. Technologies of Landscape: From Reaping to Recycling. Amherst, University of Massachusetts Press, 1999.

Peeples, Jennifer A. "Toxic Sublime: Imaging Contaminated Landscapes." Environmental Communication: A Journal of Nature and Culture, vol. 5, no. 4. 2011: 373-392. 
Phillips, Dana. "Thoreau's Aesthetics and 'The Domain of the Superlative'." Environmental Values, vol. 15, no. 3, 2006: 293-305.

Purdy, Jedediah. After Nature: A Politics for the Anthropocene. Cambridge, Harvard University Press, 2016.

Shaw, Philip. The Sublime. London, Routledge, 2007.

Slovic, Scott. "Epistemology and Politics in America Nature Writing: Embedded Rhetoric and Discrete Rhetoric." Green Culture: Environmental Rhetoric in Contemporary America. Edited by Carl George Herndl and Stuart C. Brown. University of Wisconsin Press, 1996: 82-110.

Thoreau, Henry D. A Week on the Concord and Merrimack Rivers. New York, Literary Classics of the United States, 1985.

Thoreau, Henry D. "A Winter Walk." The Portable Thoreau. Edited by Jeffrey S. Cramer. Penguin Books, 2012: 29-47.

Thoreau, Henry D. "Civil Disobedience." The Portable Thoreau. Edited by Jeffrey S. Cramer. Penguin Books, 2012: 75-100.

Thoreau, Henry D. KTAADN. The Portable Thoreau. Edited by Jeffrey S. Cramer. Penguin Books, 2012: 45-71.

Thoreau, Henry D. Natural History of Massachusetts. The Portable Thoreau. Edited by Jeffrey S. Cramer. Penguin Books, 2012: 3-25.

Thoreau, Henry D. Walden. The Portable Thoreau. Edited by Jeffrey S. Cramer, Penguin Books, 2012: 197-468.

Worster, Donald. The Wealth of Nature: Environmental History and the Ecological Imagination. New York, Oxford University Press, 1994.

Zwart, Hub. Understanding Nature: Case Studies in Comparative Epistemology. New York, Springer, 2008. 